\title{
SEDIMENTS AND AGE OF TERRACES AND FLOODPLAINS OF THE EZOUSAS RIVER IN SW CYPRUS
}

DOI: https://doi.org/10.18509/AGB.2021.01

UDC: $551.435 .13(564.3)$

\section{Tomasz Kalicki ${ }^{1}$, Sławomir Chwałek ${ }^{1}$, Paweł Przepióra ${ }^{1}$, Marcin Frączek ${ }^{1}$, Piotr Kusztal ${ }^{1}$, Mariusz Chrabąszez ${ }^{1}$, Cyryl Konstantinovski Puntos ${ }^{2}$}

\section{${ }^{1}$ Institute of Geography and Environmental Sciences, Jan Kochanowski University in Kielce, Poland ${ }^{2}$ AGH University of Science and Technology in Krakow, Poland;}

corresponding author: tomaszkalicki@ymail.com

\author{
submitted: 02.04 .2020 \\ accepted: 07.06.2020 \\ published: 30.09 .2020
}

\begin{abstract}
Since 2014 Jan Kochanowski University in Kielce participate in the research in Paphos region in SW Cyprus. The aim of geomorphologic study was the age and sediments of terraces and floodplains in Ezousas river valley. Results of TL dating indicate distinct differentiation in fluvial activity in the Late Pleistocene and Holocene. Two main alluviation phases were distinguish: 75-48 ka and 25-13 ka. Relief and the varied tectonic movements had a great impact on the valley formation and alluvial features.
\end{abstract}

Keywords: Cyprus, Ezousas river, Pleistocene, Holocene, fluvial geomorphology.

\section{INTRODUCTION}

Cyprus is located in the eastern part of the Mediterranean Sea, in the Mediterranean zone, which is a clearly distinguished physicgeographical region (Fig. 1). In contrast to the rest of the eastern Mediterranean, the island is located between the Anatolian Plateau and the foreland of the African Plate. This area is characterized by high neotectonic activity, varied relief and subtropical climate. The uplift rate of Paphos region, calculated from the high of MIS 7 and MIS 5 uplifted maritime terraces, is $0.35-0.39 \mathrm{~mm} /$ year during the Upper Pleistocene [2]. The study area covers the Ezousas river basin (Fig. 2). The spring of the river is located in the Troodos Mountains and the estuary in the Mediterranean Sea, some kilometers to the east from the Paphos city.

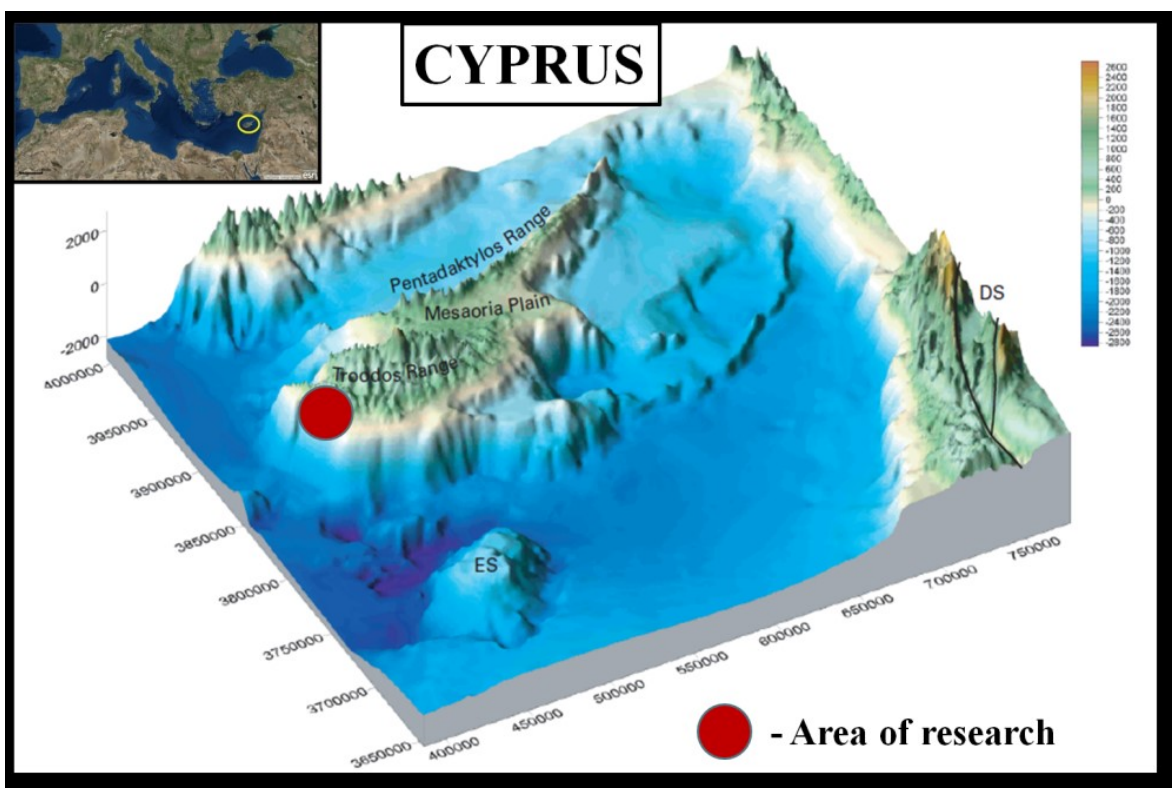

Figure 1. Location of study area (red arrows) in NE Poland, Podlasie province. 


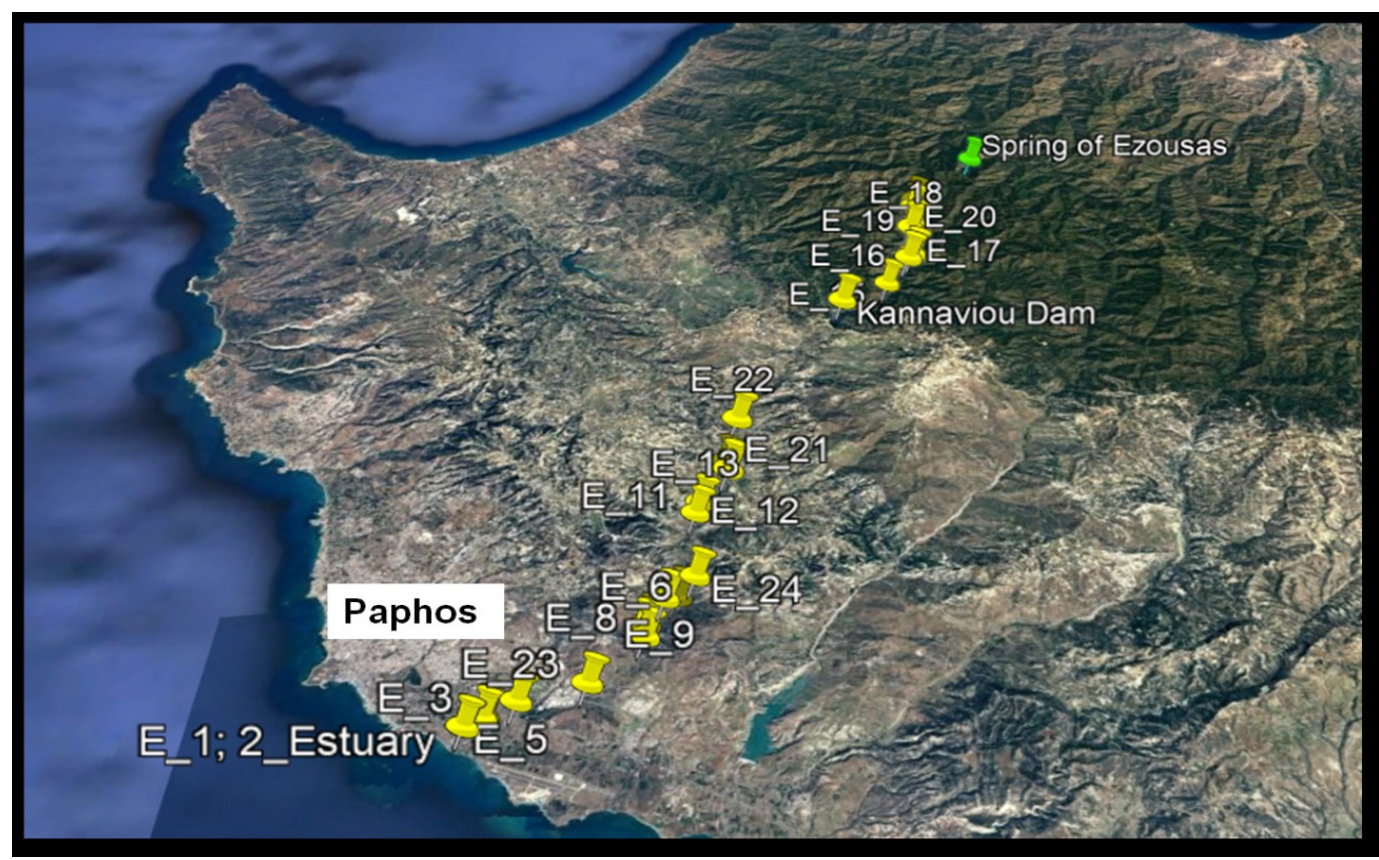

Figure 2. Cyprus, Ezousas river valley with the location of study profiles (E1-E24).

\section{AIM OF STUDY AND METHODS}

The research was conducted in 2014-2018 [3]. The aim of geomorphologic study was the age and sediments of terraces and floodplains in Ezousas river valley [4], [5], [6], [7], [8], [9]. The geomorphologic prospections were carried out along the Ezousas river valley from the sea to the spring. The field work included geological mapping and sedimentological analysis of sandy gravel alluvium of various terrace and flood plain levels.

\section{RESULTS}

The Ezousas river cross two main geological units ranging from igneous rocks in its upper section (Troodos Terrane) to sedimentary rocks in its middle and lower sections (Circum Troodos Sedimentary Succession). Depending on the section, different terrace and floodplain levels can be distinguish.

Uppersection Erosion-accumulative terrace about $30.0 \mathrm{~m}$ above river level (a.r.1.) and floodplain 0.3
Grain size field analysis based on Rutkowski's method [10], [11], petrographic analysis using a polarized light microscope and 21 samples for TL/OSL dating were also done. Dating of alluvium by TL method was conducted in the ScientificDidactic Laboratory of the Institute of Geography and Environmental Sciences of Jan Kochanowski University in Kielce. $\mathrm{m}$ a.r.l. occur in the upper section (Fig. 3A). It had been dated to $53.3 \pm 8 \mathrm{ka}$ (Fig. $3 \mathrm{~B}$ ) and to $19.7 \pm 2.9$ $\mathrm{ka}$, respectively (Table 1). Characteristic feature of alluvium in this section is large part (up to 24\%) of none-rounded grains. There are colluvium deposits transported from the rockwalls and steep slopes of the valley (Fig. 3A)

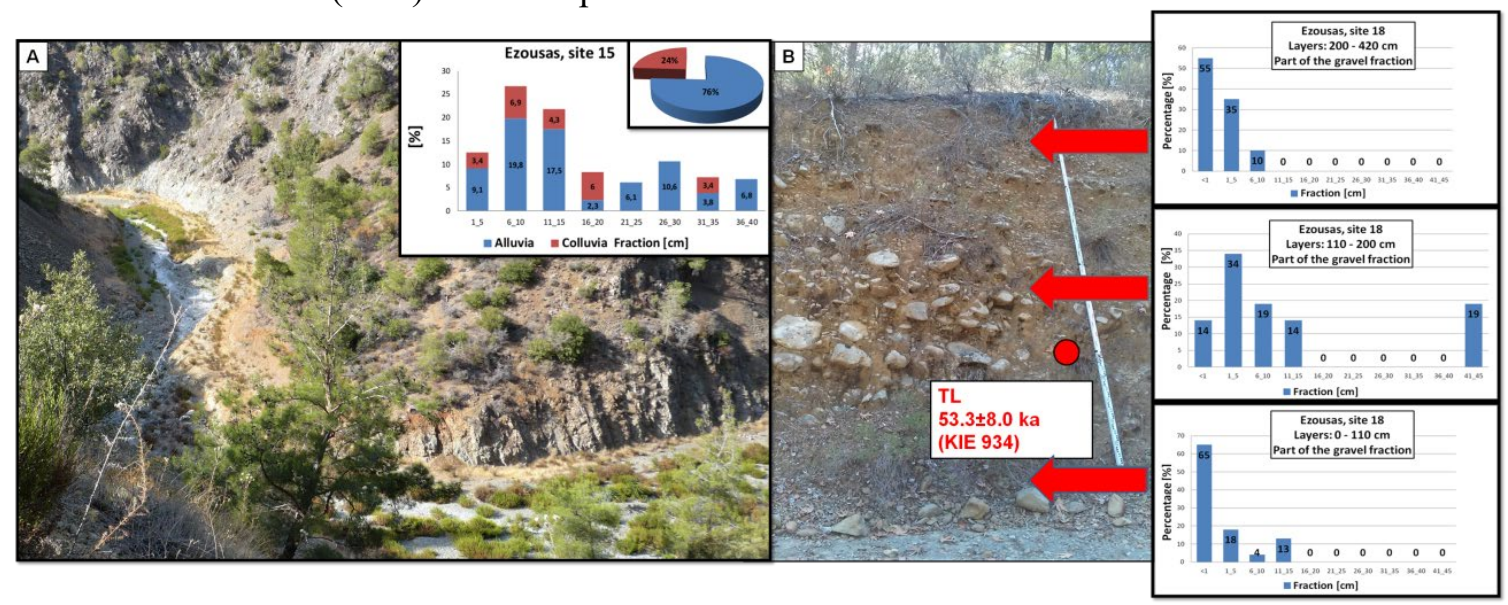

Figure 3. The upper section of the Ezousas river valley. General view and grain size analyses from the sites Ezousas 15 (A) and Ezousas 18 (B) with TL datings. 
Table 1. TL datings from the upper Ezousas river valley.

\begin{tabular}{|c|c|c|c|c|c|c|c|}
\hline & Sample & Dose $\boldsymbol{\alpha}$ & Dose $\boldsymbol{\beta}$ & Dose $\boldsymbol{\gamma}$ & $\begin{array}{c}\text { Obtained data } \\
{[\text { ka] }}\end{array}$ & $\begin{array}{c}\text { Height } \\
{[\mathbf{m} \text { a.r.l.] }}\end{array}$ & No. lab. \\
\hline 1 & Ezousas 18 & 0.0068 & 0.1472 & 0.0674 & $\mathbf{5 3 . 3} \pm \mathbf{8 . 0}$ & 30.0 & KIE-934 \\
\hline 2 & Ezousas 17 & 0.0116 & 0.2766 & 0.1278 & $\mathbf{1 9 . 7 \pm 2 . 9}$ & 0.3 & KIE-933 \\
\hline
\end{tabular}

\section{Middle section}

In the middle section of Ezousas river valley accumulative levels occurred. The highest level of $2.6 \mathrm{~m}$ a.r.1 was described as Holocene alluvia (Sequence EZG). The grading lower unit of this series with a sherd dated to $1300 \mathrm{AD}$ was accumulated in 4 phases with variable velocity of the stream. The poorly sorted structure of the upper unit above was a result of a single flood event. After the flooding, the river deposited overbank sediments in the top of outcrop [12]. Flood plain level of $1.0 \mathrm{~m}$ a.r.1. has been dated to $63.2 \pm 9.5 \mathrm{ka}$ (Table 2). Next level is $0.5 \mathrm{~m}$ a. r. 1 . and it is dating to $13.6 \pm 2.0 \mathrm{ka}$. Subsequent four sites were situated on the same high $0.2 \mathrm{~m}$ a.r.l. and alluvium were dated to $63.1 \pm 9.5 \mathrm{ka}$, (Fig. 4) $42.6 \pm 6.4 \mathrm{ka}, 37.0 \pm 5.6$ $\mathrm{ka}$ and to $2.35 \pm 0.35 \mathrm{ka}$. Two dates occur from the lowest level about $0.1 \mathrm{~m}$ a.r.l. The remnant of older series exposed in the valley floor was dated to $406.0 \pm 61.0 \mathrm{ka}$. The sample was under the boulder which fell down from the nearest rockwall probably during the earthquake [5] was dating to $28.6 \pm 4.3 \mathrm{ka}$. Alluvium in this section are finer and without colluvium part..

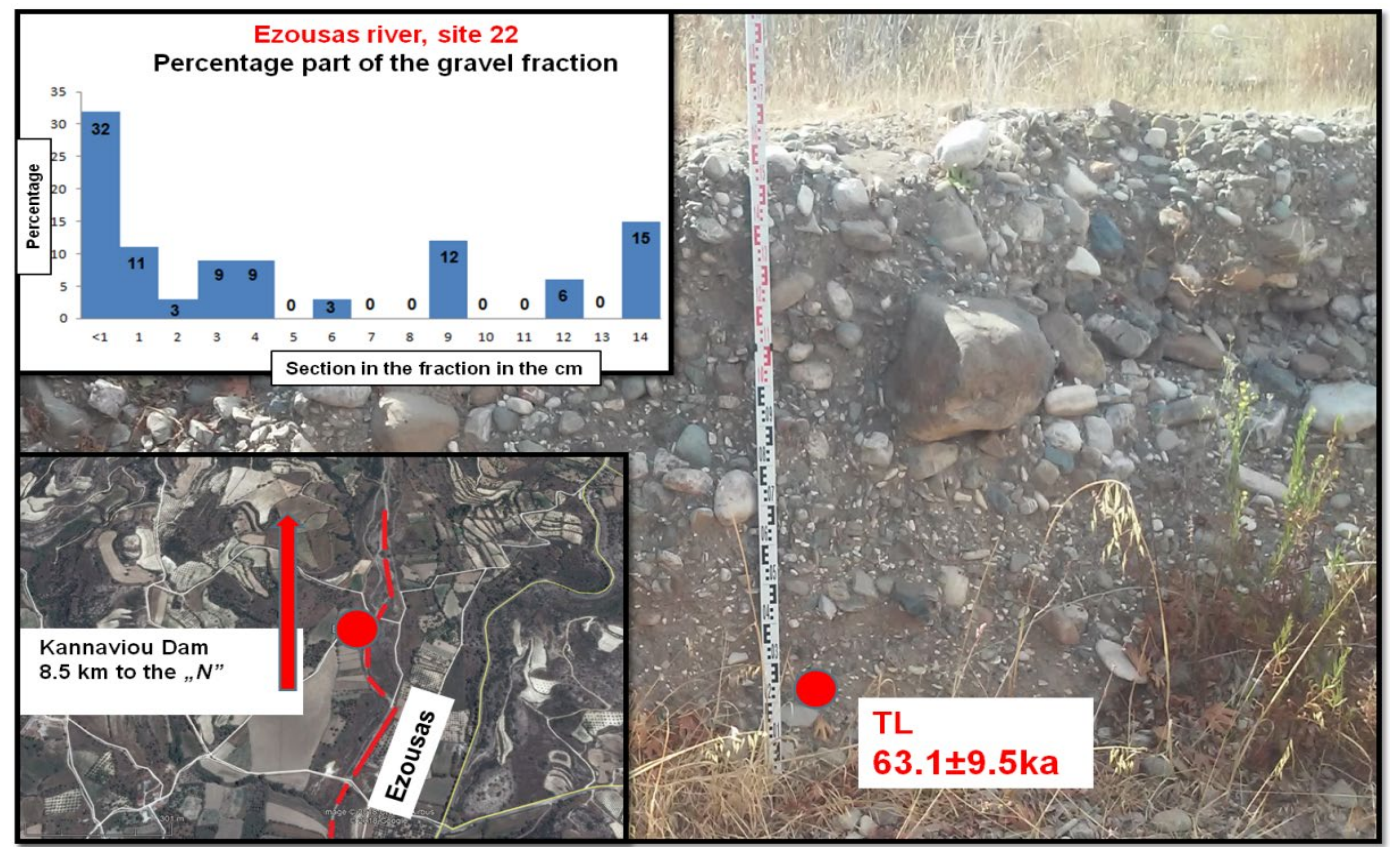

Figure 4. Site Ezousas 22 in the middle part of the river.

Table 2. TL (by authors) and archaeological datings [12] from middle Ezousas river valley.

\begin{tabular}{|c|c|c|c|c|c|c|c|}
\hline & Sample & Dose $\alpha$ & Dose $\beta$ & Dose $\gamma$ & $\begin{array}{l}\text { Obtained } \\
\text { data [ka] }\end{array}$ & $\begin{array}{c}\text { Height } \\
\text { [m a.r.l.] }\end{array}$ & No. lab. \\
\hline 1 & Ezousas 10/1 & 0.0740 & 0.9827 & 0.6431 & $63.2 \pm 9.5$ & 1.0 & KIE-945 \\
\hline 2 & Ezousas 8/1 & 0.0601 & 0.7703 & 0.5025 & $\begin{array}{c}99.25 \pm 14.89 \\
\text { modern }\end{array}$ & 1.0 & KIE-929 \\
\hline 5 & Ezousas 8/2 & 0.0686 & 1.0350 & 0.6195 & $13.6 \pm 2.0$ & 0.5 & KIE-930 \\
\hline 6 & Ezousas 22 & 0.0369 & 0.5483 & 0.3250 & $63.1 \pm 9.5$ & 0.2 & KIE-935 \\
\hline 3 & Ezousas 10/2 & 0.0257 & 0.4095 & 0.2366 & $42.6 \pm 6.4$ & 0.2 & KIE-946 \\
\hline 4 & Ezousas 7/1 & 0.0432 & 0.5651 & 0.3593 & $2.35 \pm 0.35$ & 0.2 & KIE-943 \\
\hline 7 & Ezousas 13 & 0.0465 & 0.5947 & 0.3810 & $37.0 \pm 5.6$ & 0.2 & KIE-932 \\
\hline 8 & Ezousas 12 & 0.0394 & 0.5291 & 0.3309 & $406.0 \pm 61.0$ & 0.5 & KIE-931 \\
\hline 9 & Ezousas 24 & 0.0759 & 1.094 & 0.6596 & $28.6 \pm 4.3$ & 0.1 & KIE-941 \\
\hline 10 & Ezousas 9/1 & 0.0696 & 0.7312 & 0.5174 & $\begin{array}{c}-32.01 \pm 4.8 \\
\text { modern }\end{array}$ & 0.1 & KIE-944 \\
\hline 11 & Sequence EZG & \multicolumn{3}{|c|}{ Pottery fragment (sherd) } & $\approx 1297 \mathrm{AD}$ & 2.6 & EZG1 [12] \\
\hline
\end{tabular}




\section{Lower section}

In the lower section of the Ezousas river valley, the highest erosion-accumulative terrace on limestone monocline is $30.0 \mathrm{~m}$ a.r.1. Two alluvial series in superposition occurred here. The upper one, about $5 \mathrm{~m}$ thick, is dating to $18.9 \pm 2.8 \mathrm{ka}$ very similar to landslide block at $25.0 \mathrm{~m}$ a.r.l. of this alluvium $22.4 \pm 3.4 \mathrm{ka}$ (Table 3). The lower series at $26.5 \mathrm{~m}$ a.r.l. was dating to $57.4 \pm 8.6 \mathrm{ka}$. Next were located on accumulative levels. Terrace $11.0 \mathrm{~m}$ a.r.l. was dated to $57.9 \pm 8.7 \mathrm{ka}$ (Fig. 5) and level about $2.5 \mathrm{~m}$ a.r.1. to $64.8 \pm 9.7 \mathrm{ka}$. Flood plain levels about $1.2 \mathrm{~m}$ a.r.1. and $0.2 \mathrm{~m}$ a.r.1. were dated to $22.3 \pm 3.3 \mathrm{ka}$ and to $16.1 \pm 2.4 \mathrm{ka}$ respectively. The thickness of the Pleistocene alluvium cut and fills is bigger than in the middle and upper reaches. The. Holocene sediments (Sequence EZA) are also described in this section. Alluvium from the Roman period (1.5 $\mathrm{m}$ a.r.1.) were covered by Roman and Medieval colluvium $2.5 \mathrm{~m}$ thick [12].

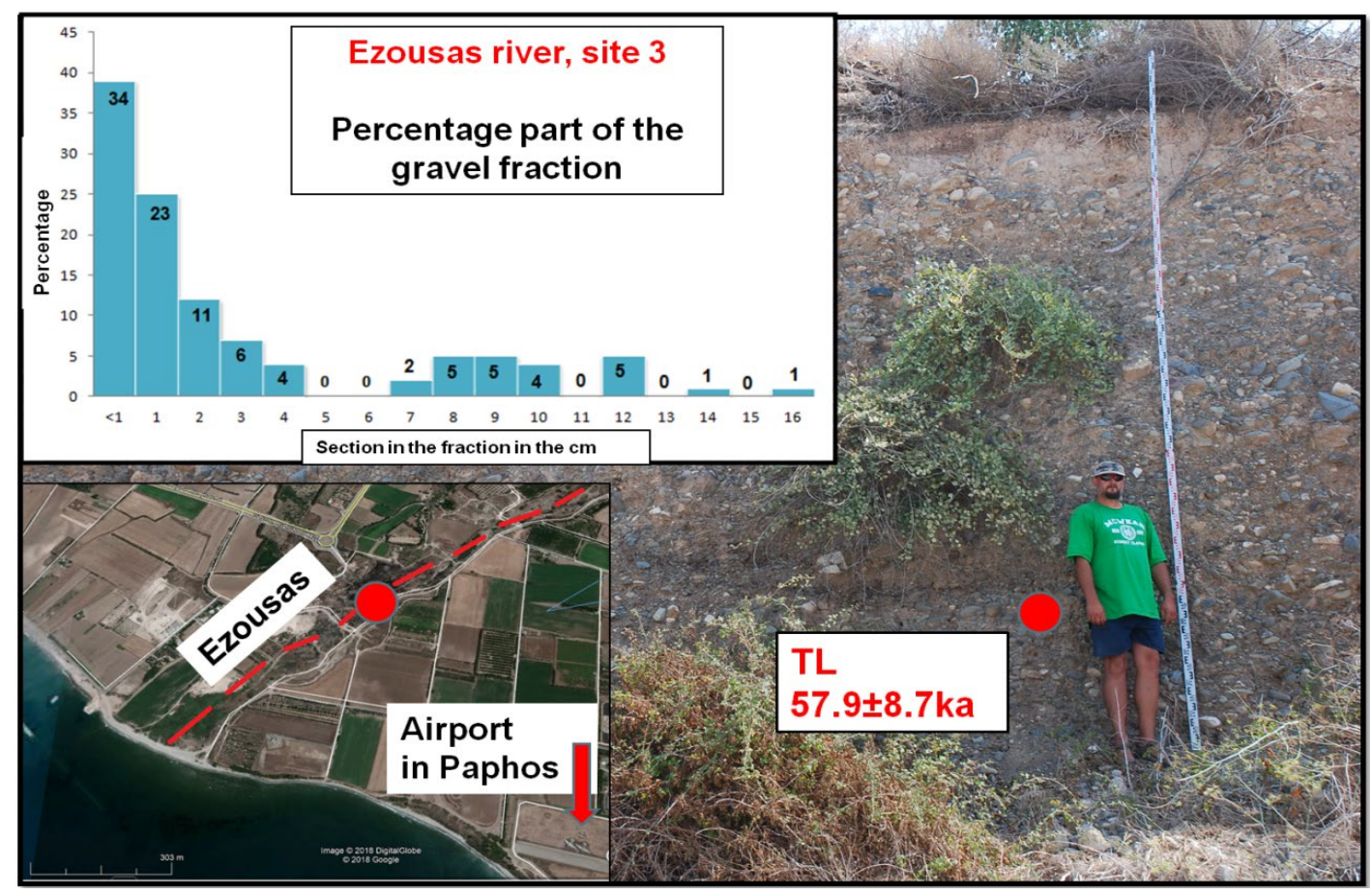

Figure 5. Site Ezousas 3 in the lower section of the river valley.

Table 3. TL (by authors), OSL and archaeological datings [12] from lower Ezousas river valley.

\begin{tabular}{|c|c|c|c|c|c|c|c|}
\hline & Sample & Dose $\alpha$ & Dose $\beta$ & Dose $\gamma$ & $\begin{array}{c}\text { Obtained data } \\
{[\mathrm{ka}]}\end{array}$ & Height [m a. r. l.] & No. lab. \\
\hline 1 & Ezousas $23 / 3$ & 0.0191 & 0.3010 & 0.1796 & $18.9 \pm 2.8$ & 30.0 & KIE-938 \\
\hline 2 & Ezousas 23/2 & 0.0263 & 0.3749 & 0.2190 & $57.4 \pm 8.6$ & 26.5 & KIE-939 \\
\hline 3 & Ezousas 23/1 & 0.0324 & 0.4966 & 0.2896 & $22.4 \pm 3.4$ & 25.0 & KIE-940 \\
\hline 4 & Ezousas 3/1 & 0.0381 & 0.6673 & 0.3791 & $57.9 \pm 8.7$ & 11 & KIE-926 \\
\hline 5 & Ezousas 5/2 & 0.0624 & 0.7030 & 0.4829 & $64.8 \pm 9.7$ & 2.5 & KIE-947 \\
\hline 6 & Ezousas 5/1 & 0.0529 & 0.7223 & 0.4432 & $\begin{array}{c}-461 \pm 61,24 \\
\text { modern }\end{array}$ & 1.3 & KIE-928 \\
\hline 7 & Ezousas 4/1 & 0.0794 & 1.0518 & 0.6733 & $22.3 \pm 3.3$ & 1.2 & KIE-927 \\
\hline 8 & Ezousas 4/2 & 0.0257 & 0.4095 & 0.2366 & $16.1 \pm 2.4$ & 0.2 & KIE-942 \\
\hline 9 & Sequence EZA & \multicolumn{3}{|c|}{ Pottery fragment (sherd) } & $\approx 358 \mathrm{BC}$ & 1.5 & EZA2 [12] \\
\hline 10 & Sequence EZA & \multicolumn{3}{|c|}{ Pottery fragment (sherd) } & $\approx 134 \mathrm{AD}$ & 1.5 & EZA4 [12] \\
\hline 11 & Sequence EZA & & & & $2.8 \pm 0.4$ & depth 2.2 colluvium? & $\begin{array}{c}\text { OSL EZA } \\
1[12]\end{array}$ \\
\hline 12 & Sequence EZA & & & & $0.94 \pm 0.07$ & depth 1.3 colluvium & $\begin{array}{c}\text { OSL EZA } \\
4[12]\end{array}$ \\
\hline
\end{tabular}

\section{CONCLUSIONS}

In the Ezousas river valley there were very strong alluviation in the Pleistocene and small one in the Holocene. Two main alluviation phases can be distinguish: 75-48 ka and 25-13 ka (Fig. 6). There is no geological data about increased neotectonic movements in these phases. Therefore, an increased alluviation in Cyprus have been probably associated with climate change.. Similar fact is also 
confirmed in the valleys of SE Poland [13]. In both phases the correctness of the increase in the number of dates along the course of the river occurred. This is caused by a clear intensification of the erosion process in the mountain section of the river, where few alluvial covers have been preserved and a distinct alluviation (accumulation) in the middle and lower sections.

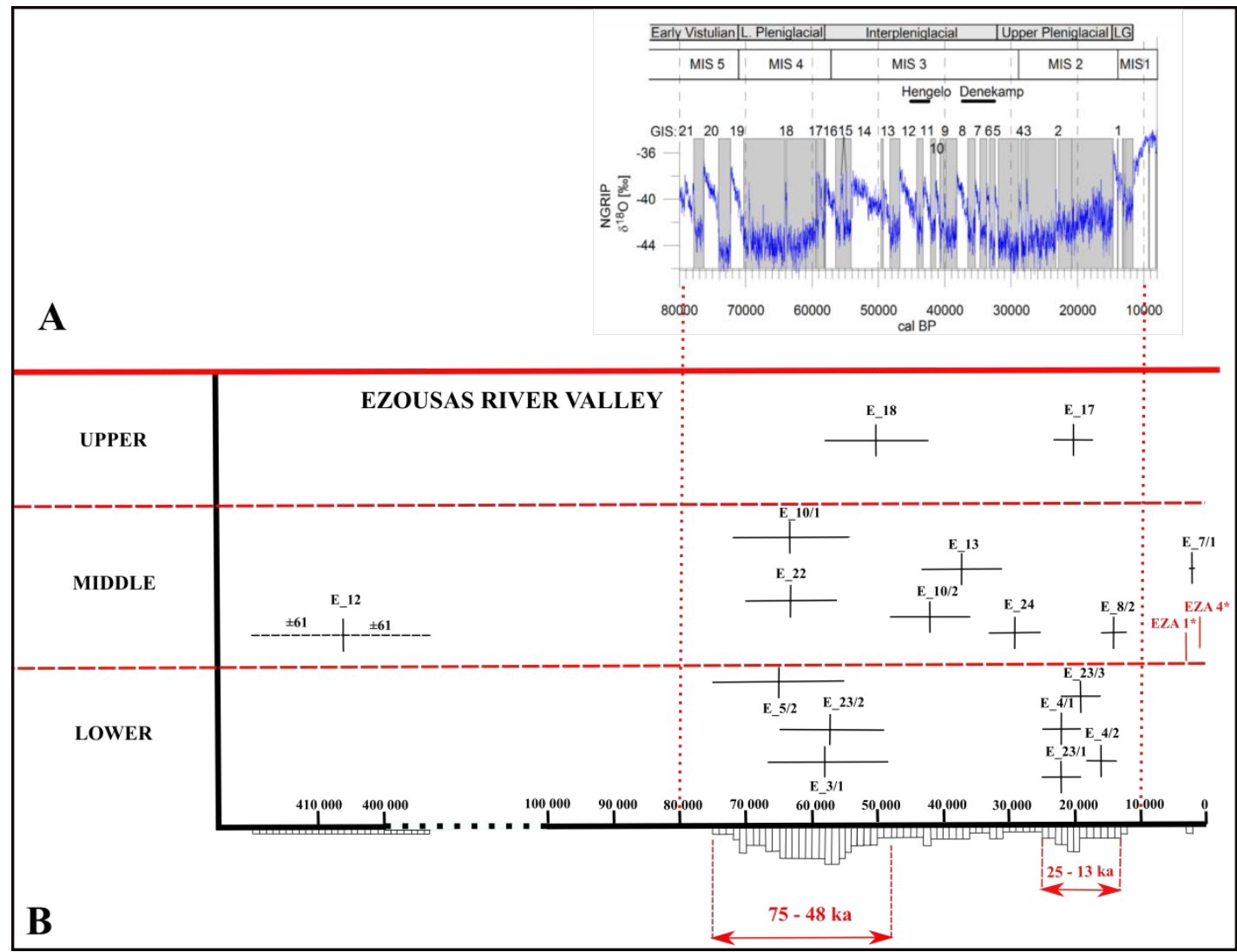

Figure 6. A: Greenland ice core records [13], B: TL records from Ezousas river valley.

The results of mineralogical and petrographic analysis show compliance with the geological map units. Petrographic analysis of geological outcrops and gravels from alluvia made it possible to determine the place of alimentation of clusters in the riverbed. The maximum confirmed transport length in the Holocene was about $7 \mathrm{~km}$. This confirms the small role of fluvial transport in the Holocene, which is consistent with data obtained from TL/OSL dating, hydrological data and measurements of present-day fluvial processes. Relief and the varied tectonic movements had a great impact on the Ezousas valley formation and alluvial features. The number of colluvium in alluvium decreases with the length of the river. The high rate of Cyprus uplift caused that in the upper, mountain section the rate of river incision in the period of 60-20 ka was about $30 \mathrm{~m}$. However, in the wider, middle section located in front of the Troodos Mts. within the sedimentary margin of these mountains, the cut and fill of different age (400-2 ka) are located at almost one morphological level. Only the Medieval cut and fill is about $2 \mathrm{~m}$ higher, but the aggradation of this period probably did not cover the entire bottom of the valley, only a fragment of the alluvial braided plain. In the lower section, the river crosses the tectonic horst, which was uplifted about $30 \mathrm{~m}$ during the last $20 \mathrm{ka}$. Two alluvial series (57 ka and 22-19 ka) rest on it (Ezousas 23 site) in superposition. Uplift the lowest section of the valley crossing maritime terraces can be estimated at about $11 \mathrm{~m}$ during $60 \mathrm{ka}$. An accumulation of the great landslide in the dry riverbed near Episkopi was probably triggered by earthquake, very frequent in Cyprus. It took place about 28.6 ka (Ezousas 24 site).

\section{ACKNOWLEDGMENTS}

The study are part of Agora Paphos Project financed by The National Science Centre: grant NCN MAESTRO 2014/14/A/HS3/00283 „Agora oraz infrastruktura i aktywność gospodarcza Pafos, stolicy hellenistycznego i rzymskiego Cypru na podstawie badań interdyscyplinarnych" 


\section{REFERENCES}

[1] Harrison, Richard, Newell, Wayne, Panayides, Ioannis, Stone, Byron, Tsiolakis, Efthymios, Necdet, Mehmet, Batihanli, Hilmi, Ozhur, Ayse, Lord, Alan, Berksoy, Okan, Zomeni, Zomenia, and Schindler, J.S. Bedrock geologic map of the greater Lefkosia area, Cyprus: U.S. Geological Survey Scientific Investigations Map 3046, 1 map, scale 1:25,000, pp. 36, 2008.

[2] Zomeni Z. Quaternary Marine Terraces on Cyprus: Constraints on Uplift and Pedogenesis and the Geoarchaeology of Palaipafos (A DISSERTATION submitted to Oregon State University, manuscript), pp. 120, 2012.

[3] Kalicki T., Krupa J., Chwałek S. Geoarchaeological studies in Paphos-first results, [in:] J. Bodzek (ed.), Studies in Ancient Art and Civilization 19, Krakow, pp. 233 254, 2015.

[4] Kalicki T., Chwałek S., Frączek M., Kusztal P., Przepióra P. Geoarcheologia/Geoarchaeology [in:] E. PapuciWładyka (red./ed.), Pafos - misterium miasta Afrodyty. Dziedzictwo archeologiczne a nowe technologie/Paphos Mystery Of The City Of Aphrodit. Archaeological Heritage Versus New Technologies, Kraków, pp 162-171, 2018.

[5] Kalicki T., Chwałek S., Frączek M., Kusztal P., Przepióra P., Czerniak R., Chrostodolou G. Late Quaternary phases of alluviation in the river valleys around Paphos, Abstract Book $9^{\text {th }}$ International Symposium on Eastern Mediterranean Geology,7-11.05.2018, Antalya, Turkey, pp 208-209, 2018.

[6] Kalicki T., Chwałek S., Frączek M., Przepióra P., Chrabąszcz M., Kusztal P. Sediments and age of terraces and floodplains of the Ezousas river, [in:] L. Kleprliková, J. Šamánek, T. Turek, G. Calábková, Martin Ivanov (eds.), Sbornik abstraktů 24. Kvarter, 30.11.2018, pp 30, Brno, 2018.

[7] Kalicki T., Chwałek S., Przepióra P., Konstantinovski Puntos C. Boulder at Episkopi in Ezousas Valley (SW Cyprus) as indicator of seismic and mass movement event, [in:] L. Kleprliková, J. Šamánek, T. Turek, G. Calábková, Martin Ivanov (eds.), Sbornik abstraktů 24. Kvarter, 30.11.2018, pp 31, Brno, 2018.

[8] Chwałek S., Kalicki T, Pleistocene terraces and floodplains of the Ezousas river in SW Cyprus, [in:] L. Kleprliková, A. Plichta, T. Turek (eds.), Sbornik abstraktů 25. Kvarter, 29.11.2019, pp 27, Brno, 2019.

[9] Kalicki T., Chwałek S., Konstantinovski Puntos C., First results of petrographic and sedimentologic studies of the Ezousas river gravels (SW Cyprus), [in:] L. Kleprliková, A. Plichta, T. Turek (eds.), Sbornik abstraktů 25. Kvarter, 29.11.2019, pp 31, Brno, 2019.

[10] Rutkowski J. Uziarnienia osadów bardzo gruboziarnistych - możliwości badawcze [in:] E. Mycielska-Dowgiałło, J. Rutkowski (eds.), Badania cech teksturalnych osadów czwartorzędowych i wybrane metody oznaczania ich wieku, Wydawnictwo Szkoły Wyższej Przymierza Rodzin, Warszawa, pp. 9-16, 2007.

[11] Bluszcz A., Starkel L., Kalicki T. Grain size composition and age of alluvialsediments in the Tista valley floor near Kalijhora, Sikkim Himalaya, Studia Geomorphologica Carpatho-Balcanica 31, pp. 159-174, 1997.

[12] Deckers K. Geoarchaeological evidence from Western Cyprus: indications on the impact of people on the environment and of the environment on human communities. Atti della Società Toscana di Scienze Naturali, Memorie, Serie A, 112, pp. 105-113, 2007.

[13] Starkel L., Michczyńska D., Gębica P. Reflection of climatic changes during interpleniglacial in the geoecosystems of South-Eastern Poland, Geochronometria, 44, pp. 202-215, 2017. 